\title{
Combining Microsatellite Markers and Ampelography for Better Management of Romanian Grapevine Germplasm Collections
}

\author{
Carmen F. POPESCU ${ }^{1 *}$, Manna CRESPAN ${ }^{2}$ \\ ${ }^{1}$ National Research and Development Institute for Biotechnology in Horticulture (NRDIBH) Stefanesti-Arges, Sos. Bucuresti-Pitesti, no. 37, \\ Stefanesti, CP 117715, County_Arges, Romania; carm3n_popescu@yahoo.com (*corresponding author) \\ ${ }^{2}$ Council for Agricultural Research and Economics - Centre of Viticulture and Enology Research, Via XXVIII Aprile 26, 31015 Conegliano (TV), \\ Italy;manna.crespan@crea.gov.it
}

\begin{abstract}
Aiming to investigate the correspondence of phenotypic variability and molecular markers, 50 varieties of Vitis vinifera ssp. vinifera, ancient grapevine varieties grown on Romanian territory, were selected to be analysed. All varieties were subjected to ampelographic analyses with OIV descriptors and also to molecular analyses with 13 microsatellites. The morphology description with recommended methods corresponded with the reference literature, proving the correct registration of the varieties at the moment of acquisition. Markers efficiency for assessing the genetic diversity among studied varieties was evaluated by computation of statistic parameters referring to the polymorphisms found. Among the internationally recommended SSR markers, ISV4 and VMCNG4b9 markers displayed interesting PIC and PI values. By comparing the SSR profiles of the 50 Romanian grapevine varieties with those in the EU database, the following can be concluded: confirmation of 10 synonymies mentioned in old documents, while 3 synonymies mentioned in old reference literature were not confirmed, new synonyms were found for 4 accessions, additional synonyms were found for 4 accessions, which are to be added to the previous ones already mentioned in the literature, the synonymies in three groups of accessions were documented for the first time in the specialised literature, the unicity of three Romanian accessions was proved ('Moroştină', 'Negru mare' and 'Românie') and the genetic profiles of 15 varieties were identical to those already recorded in the investigated databases.
\end{abstract}

Keywords: autochthonous cultivars; genotyping; homonyms; synonyms; SSR markers

\section{Introduction}

A comprehensive characterization of accessions preserved in germplasm collections entails ampelographic description with standardized descriptors and molecular analyses with an internationally shared set of SSR markers. The two approaches ensure accurate identification and guarantee the authenticity of plant material used in research work, preserved in germplasm collections, or distributed for establishing new vineyards. The first international standard for the classification of grapevine based on morphological characters was established in 1873 by the International Ampelography Committee in Vienna. Permanently improved, this system for describing and characterizing species and varieties of Vitis genus comprises today 150 descriptors, of which 48 are essential.

Since the mid-1990s, in addition to the descriptor system, microsatellite markers have been used for the genetic characterization of grapevine varieties, as a useful tool complementing ampelography. Thomas et al. (1993) first applied the SSR analysis for identifying grapevine varieties and their results showed that the microsatellite sequences are: a) abundant in the genome; b) highly informative for identifying Vitis vinifera varieties; c) transmitted to descendants following the Mendelian laws of heredity (co-dominant); d) suitable for genetic mapping and investigation of the degree of genetic relatedness among genotypes. The main advantage of microsatellite sequences is the high reproducibility, which allows the exchange of data between laboratories around the world, the final result being a unique genetic profile for each variety and, implicitly, unambiguous characterization of any variety.

These features were considered underpinned for the OIV decision to recommend in 2009 the use of six SSR loci to identify Vitis genotypes (OIV, 2009). Subsequently, after testing improved methods on a number of over 2,000 genotypes, belonging to 30 germplasm collections, nine SSR markers were finally recommended (Maul et al., 2012). Thus, identifying grapevine varieties using at least 9 SSRs 
194

has become a common practice for synonyms and homonyms detection, preliminary investigation on genetic relatedness between or among varieties, and identification of plant materials of unknown origin by comparing their profiles with reference genotypes collected in the international databases.

Grapevine germplasm collections in Romania have a wide range of varieties, an overwhelming majority having a long tradition of vineyard culture. The series of seven "Ampelografia of the Romanian People's Republic" published between 1959 and 1966 with the detailed description of the old grapevine varieties and the works of Indreas and Visan (2001) and Rotaru (2009) about those considered of economic importance, are the reference literature for the field of ampelography. In the last two decades, for many of the vine varieties considered valuable and important for the production of grapes and wine, the ampelographic description was completed with molecular characterization (Bodea et al., 2009; Butiuc-Keul et al., 2010; Coste et al., 2010; Gheorghe et al., 2008; Ghețea et al., 2010 and 2012; Popescu et al., 2017).

The objectives of this study were: 1) to complete the identification of some grapevine varieties, supposed to be autochthonous, on the base of 48 OIV descriptors and 13 SSR markers; 2) to evaluate the genetic diversity of the analysed Romanian grapevine varieties.

\section{Materials and Methods}

\section{Biologicalmaterial}

Table 1 presents the fifty (50) varieties of grapevine used in the present study and selected because considered indigenous and cultivated for many centuries in our country. All of them are growing in the ex situ germplasm collection held by NRDIBH Stefanesti.

\section{Morphological description}

For ampelographic description, 48 standardized OIV descriptors for grapevine (OIV, 2009) were applied, following the recommended methodology; they refer to: young shoot (OIV 001, 003, 004, 006, 007, 008 and 016), young and mature leaf (OIV 051, 053, 067, 068, 070, 072, $074,075,076,079,080,081-1,081-2,083-2,084,087$ and 094), type of flower, bunch and berry aspects (OIV 151, 155, 202, 204, 206, 208, 209, 220, 221, 223, 225, 231, 235, 236 and 241), phenology, growth, quality and quantity of grape yield (OIV 301, 303, 351, 502, 503, 504, 505, 506 and 508).

\section{Protocol for molecular analyses}

For molecular analyses, the DNA extraction was performed from $100 \mathrm{mg}$ fresh leaf with Qiagen DNeasy Plant mini-kit (Qiagen, Hilden, Germany). For genotyping were used 13 SSR markers: nine of them belonged to the set of those internationally recommended (Maul et al., 2012) as a standard for grapevine (VVS2, VVMD5, VVMD7, VVMD25, VVMD27, VVMD28, VVMD32, VrZAG62 and VrZAG79), plus additional four, namely ISV2, ISV3, ISV4 and VMCNG4b9. The SSR analyses were performed following the protocol described by Migliaro et al. (2013), using fluorescent primers and an ABI3130xl genetic analyser (Applied Biosystems, Foster City, CA).

\section{Statistical analysis}

Data analysis: statistics on scored alleles were computed, such as the number of alleles $(\mathrm{Na})$, the number of effective alleles $(\mathrm{Ne})$, observed heterozygosity $(\mathrm{Ho})$, expected heterozygosity $(\mathrm{He})$, polymorphism information content (PIC), the probability of identity (PI), and the probability of null alleles $(\mathrm{F}($ null) using the freely available Cervus 3.0.7 and GenAlEx softwares.

\section{Results and Discussion}

\section{Ampelographic description}

From the total of fifty (50) varieties, five (5) were very well appreciated and grown in many other countries with long time viticulture tradition, seven (7) are major local cultivars, extensively grown in Romania and two (2) are minor local cultivars, fairly utilized in wine production (Table 1). Most of the studied varieties (36) are considered autochthonous, grown for centuries on the study territory, but today rarely notified in private households, or preserved in few germplasm collections. Valuable information with detailed ampelographic descriptions was found for 44 varieties in old documents, so it was possible to obtain a preliminary confirmation of the authenticity of the corresponding accessions. No information was found for 'Braghină albă', 'Galbenă maruntă', 'Moroștină', 'Românie', 'Țâța caprei neagră' and 'Țâța vacii neagră', so it was not adequate to establish their possible authenticity only on the basis of our morphological characterization.

Ampelographic description of all varieties was performed at specific phenophases (shoot tip and young leaf, during spring; mature leaf after flowering; bunch and berry between ripening and harvesting), on target organs, in specific position on the vine and the right notifications were recorded for expression level of each character. All features and their descriptor records were compared with those in the reference literature, presenting comprehensive information for each variety. Some characters were slightly different, such as: intensity of anthocyanin coloration of the shoot tip (OIV 003), colour of upper side of the young leaf (OIV 051), shape of the mature leaf (OIV 067), degree of opening/overlapping of petiole sinus (OIV 079), shape of petiole sinus (OIV 080), density of prostrate hairs between main veins on lower side of mature leaf (OIV 084), bunch density (OIV 204), bunch shape (OIV 208), berry shape (OIV 223), sugar content of must (OIV 505) and total acidity of must (OIV 506). These differences are often explained as different response of each variety to variable cultural conditions, healthy status of the plants, observer subjectivity (Fatahi et al., 2003; Carimi et al., 2010; Tassie, 2010). In some instances, were noted varieties that were morphologically very similar varieties, so that they cannot be distinguished by visual comparison, but had different DNA profiles, and, on the contrary, clones of the same cultivar showed different phenotypes, even if their DNA profile was identical. 
Table 1. Grapevine cultivars characterized using OIV descriptors and SSR markers

\begin{tabular}{|c|c|c|c|c|c|c|}
\hline Accession name & Accession number & Berry colour & Use & Distribution* $^{*}$ & $\begin{array}{c}\text { Description - } \\
\text { Constantinescu et al. } \\
(1959-1966)\end{array}$ & $\begin{array}{c}\text { ИIVC } \\
\text { no* }^{* *}\end{array}$ \\
\hline 'Ardeleancă' & ROM051-237 & green & wine & 360 & 1959 (p. 115-126) & 904 \\
\hline 'Băbească neagră' & ROM051-238 & blue black & wine & 320 & 1959 (p. 127-154) & 843 \\
\hline 'Bacator' & ROM051-011 & rose & wine & 360 & 1959 (p. 155-168) & 905 \\
\hline ‘Băşicată’ & ROM051-239 & green & wine & 360 & 1961 (p. 121-136) & 1022 \\
\hline 'Bătută neagră' (1) & ROM045-025 & blue-black & wine/table & 360 & 1959 (p. 169-182) & 1042 \\
\hline 'Negru românesc' (1) & ROM045-172 & black & wine & 360 & 1966 (p. 93-104) & 1042 \\
\hline 'Berbecel' & ROM051-240 & green & wine & 360 & 1959 (p. 183-194) & 1148 \\
\hline 'Busuioacă de Bohotin' & ROM051-035 & red & wine & 320 & 1960 (p. 615-628) & 8248 \\
\hline 'Iordană' & ROM051-113 & green & wine & 320 & 1960 (p. 7-18) & 5544 \\
\hline 'Gordan' & ROM051-257 & green & wine & 360 & 1961 (p. 565-576) & 5544 \\
\hline 'Zemoasă' & ROM051-273 & green & wine & 360 & 1962 (p. 669-680) & 5544 \\
\hline ‘Braghină albă’ (1) & ROM045-037 & green & wine & 360 & - & 1645 \\
\hline 'Braghină roz’ (1) & ROM045-036 & rose & wine & 360 & 1959 (p. 213-232) & 1644 \\
\hline ‘Cadarcă’ & ROM051-047 & black & wine & 320 & 1959 (р. 273-290) & 5898 \\
\hline 'Cârcioasă’ (1) & ROM045-048 & green & wine & 360 & 1965 (p. 177-188) & 935 \\
\hline ‘Cârlogancă’ & ROM051-241 & green & wine/table & 330 & 1959 (p. 485-509) & 3237 \\
\hline ‘Ceauş alb’ (1) & ROM045-051 & green & table & 360 & 1959 (p. 291-306) & 10196 \\
\hline ‘Ceauş roz’ & ROM051-242 & rose & table & 360 & 1959 (p. 307-320) & 2507 \\
\hline ‘Cioinic' & ROM051-243 & green & wine/table & 360 & 1961 (p. 327-340) & 2674 \\
\hline 'Coada oilor' & ROM051-244 & green & wine & 360 & 1962 (p. 363-375) & 5852 \\
\hline ‘Coarnă albă’ & ROM051-246 & green & wine/table & 360 & 1959 (p. 433-452) & 2724 \\
\hline 'Coarnă neagră' & ROM051-247 & black-red & table & 320 & 1959 (p. 453-469) & 2726 \\
\hline 'Coarnă roşie' & ROM051-248 & red & table & 360 & 1961 (p. 377-390) & 2728 \\
\hline 'Creață’ & ROM051-072 & green & wine/table & 360 & & \\
\hline 'Creață de Banat' & ROM051-249 & green & wine/table & 360 & 1959 (p. 470-484) & 6501 \\
\hline 'Cruciuliță' & ROM051-250 & green & wine & 360 & 1961 (p. 415-426) & 3267 \\
\hline 'Fetească albă' & ROM051-251 & green & wine & 310 & 1959 (p. 523-554) & 4119 \\
\hline 'Fetească neagră' & ROM051-252 & black & wine & 310 & 1959 (p. 555-570) & 4120 \\
\hline 'Fetească regală’ & ROM051-253 & green & wine & 310 & 1959 (p. 627-644) & 4121 \\
\hline 'Frâncuşe' & ROM051-254 & green & wine & 320 & 1959 (p. 571-592) & 4221 \\
\hline ‘Galbenă de Odobești' & ROM051-255 & green & wine & 320 & 1959 (p. 645-666) & \\
\hline 'Zghihară de Huşi' & ROM051-274 & green & wine & 320 & 1960 (p. 667-678) & 12727 \\
\hline ‘Galbenă uriaşă’’ & ROM051-256 & green & wine & 360 & 1961 (p. 512-523) & 4322 \\
\hline 'Galbenă măruntă’ (1) & ROM045-100 & green & wine & 360 & - & 5920 \\
\hline 'Gordin’ & ROM051-258 & green & wine & 360 & 1959 (p. 681-698) & 4901 \\
\hline 'Grasă de Cotnari' & ROM051-106 & green & wine & 310 & 1959 (p. 699-719) & 4948 \\
\hline 'Majarcă albă' & ROM051-259 & green-rose & wine & 360 & 1960 (p. 65-76) & 11866 \\
\hline 'Moroștină' (1) & ROM045-146 & green & wine & 360 & - & 8007 \\
\hline 'Negru mare' & ROM051-261 & black & wine/table & 360 & 1962 (p. 267-278) & 2452 \\
\hline 'Negru moale' & ROM051-262 & black & wine & 360 & 1960 (p. 215-238) & 8464 \\
\hline 'Negru vârtos' & ROM051-263 & black & wine & 360 & 1960 (p. 239-262) & 7540 \\
\hline 'Pârciu' & ROM051-265 & green & wine & 360 & 1962 (p. 423-432) & 9300 \\
\hline ‘Plăvaie’ & ROM051-166 & green & wine & 330 & 1960 (p. 353-366) & 9553 \\
\hline ‘Românie’ (1) & ROM045-206 & green & wine & 360 & - & 10177 \\
\hline ‘Tămâioasă românească’(2) & ROM06-0134 & green & wine & 310 & $1960($ p. $585-614)$ & 25546 \\
\hline ‘Tâț̦a caprei albă’' (1) & ROM045-234 & green & table & 360 & 1962 (p. 617-630) & 16449 \\
\hline 'Tâța caprei neagră' & ROM051-268 & black & table & 360 & - & 5423 \\
\hline ‘Tâța vacii albă’ & ROM051-269 & green & table & 360 & 1962 (p. 631-644) & 6419 \\
\hline 'Tâța vacii neagră' (1) & ROM045-237 & black & table & 360 & - & 25547 \\
\hline 'Vulpea' & ROM051-272 & black & wine/table & 360 & $1962(657-668)$ & 13186 \\
\hline
\end{tabular}

1) Accessions under evaluation received from Research and Development Station for Viticulture and Oenology Drăgășani; (2) Accession under evaluation received from University of Agronomic Sciences and Veterinary Medicine of Bucharest

$* 310=$ local cultivar, spread all over, international cultivar; $320=$ major local cultivar, of local importance, but extensively grown; $330=$ minor local cultivar, of local importance, fairly utilized; $360=$ local neglected cultivar, at risk of extinction

${ }^{*} V$ IVC The Vitis International Variety Catalogue is a database of various species and varieties/cultivars of grapevine. 
196

SSR profiles for identifying synonyms, homonyms, misnomers and unique genotypes

In the last 30 years, in Europe, the interest of grapevine growers and wine producers for old and autochthonous varieties has increased and therefore it became necessary to correctly identify the varieties. It is very well known that the same variety may be grown in a number of countries or regions under different names (synonyms) or different varieties may be known under the same name (homonyms). Part of this information is found in Romanian most representative literature in ampelography domain. The results obtained with SSR profiles comparison provided valuable and sometimes unexpected information for the identification of varieties and revealed new or different synonyms and homonyms. SSR profiles also allowed the detection of unique varieties and accessions incorrectly identified by means of ampelographic descriptors.

The genetic profile of each accession was obtained (Popescu et al., 2017) and the results were certified after comparison with three databases: Vitis International Variety Catalogue (VIVC) (http://www.vivc.de/), CREAViticulture and Enology molecular database (partially published) and INRA database. Forty-five different SSR profiles were obtained. Corroborating the genetic profiles for 13 SSR markers with reference literature information describing each accession, the authors came to the following conclusions:

A. The synonymies mentioned in old documents were confirmed for: 'Ardeleancă' and 'Bakator belyi'; 'Creață' and 'Creață de Banat', and 'Kreaca'; 'Bacator' and 'Bakator roz'; 'Braghină roz' and 'Braghină roșie rară'; 'Cadarcă' and 'Kadarka Kek'; 'Ceaus alb' and 'Chaouch blanc'; 'Majarca albă' and 'Slankamenka bela'; 'Negru vârtos' and 'Mavrud Varnenskii'; 'Plăvaie' and 'Plavay'; 'Tâța caprei albă' and 'Tsitsa kaprei'.

B. Some synonymies presented in reference old literature were not confirmed and new ones or different from previous statements were found:

- 'Busuioacă de Bohotin' had the same SSR profile with 'Muscat à petits grains blancs', but a different colour of the berries; thus, it can be concluded that 'Busuioacă de Bohotin' is the red somatic variant for berry colour of 'Muscat à petits grains blancs' and not a synonym with 'Muscat rouge de Madere' as mentioned Constantinescu et al. (1960);

- 'Galbenă uriaşă' SSR profile matched that of 'Mirkovaca', an endangered Croatian variety described by Maletić et al. (1999); so, the present results proved that 'Galbenă uriaşă' is not a clonal variant of 'Galbenă de Odobeşti' as mentioned Constantinescu et al. (1961);

- 'Tămâioasă românească' accession, one of the most important and appreciated grapevine varieties in Romania, was proven not to share the same SSR profile of 'Muscat à petits grains blancs', and therefore not to be a synonym with it, as mentioned by Constantinescu et al. (1960). Because the investigated accession seemed to be similar to those from other collections, it is supposed the existence of a mixture of at least two varieties of 'Tămâioasă românescă' in Romanian vineyards and, accordingly, Popescu et al. (2017) recommended the study of the mix of varieties in old 'Muscat à petits grains blancs' vineyards all over the country.
C. Synonyms were found for some accessions for which there is no information in the Romanian ampelographic literature, such as:

- 'Galbenă măruntă' SSR profile matched that of 'Kakotrygis', a Greek variety, so it is a synonym with this one;

- 'Tâța caprei neagră' SSR profile matched that of 'Hora', a well-known Bulgarian variety;

- 'Tâța vacii neagră' matched that of 'Kozi Cici cherveni', also a Bulgarian variety;

- 'Braghină albă' and 'Braghină roz' showed two different molecular profiles, so they are different varieties, not somatic variants for berry colour and with no relatedness with 'Bakator' as is supposed by Constantinescu et al. (1959).

D. New synonyms, which will be added to the previous mentioned in the literature, were proven for some varieties:

- 'Ceauş roz' has the same profile with 'Chaouch rozovyi’ from Turkey;

- 'Coada oilor' is synonym with 'Juhfark' from Hungary;

'Țâța vacii albă' showed the same SSR profile as 'Halholyag' from Ukraine;

- 'Cârcioasă' shared the same genotype with 'Balint weiss' from Hungary.

E. For the first time in Romanian literature, synonymies were documented for the following varieties:

- 'Bătută neagră' shares the same SSR profile of 'Negru românesc', though they were considered different varieties and were described separately by Constantinescu et al. in 1959 and 1966, respectively;

- 'Gordan', 'Iordană' and 'Zemoasă' accessions showed identical microsatellite profiles, proving to be synonyms;

- 'Zghihară de Huşi' and 'Galbenă de Odobești' varieties present in many germplasm collections, grown on large areas and used in wine producing, have the same SSR profiles, and proven to be synonyms.

F. The different genetic profiles obtained for 'Moroştină', 'Negru mare' and 'Românie' varieties, proved their uniqueness in the European Vitis germplasm collections.

G. Fifteen varieties showed genetic profiles identical to those already recorded for their respective names in the databases; they are: 'Băbească neagră' 'Băşicată', 'Berbecel', 'Cârlogancă', 'Cioinic', 'Coarnă albă', 'Coarnă neagră', 'Coarnă roşie', 'Cruciuliță', 'Fetească albă', 'Fetească neagră', 'Fetească regală', 'Frâncuşe', 'Grasă de Cotnari', 'Vulpea'.

The results obtained and presented in the hereby paper prove the usefulness of genotyping as a precious and convenient tool for supporting ampelography in the correct identification of varieties managed in the germplasm collections. This way, there were found similarities among accessions from Romanian collections and the varieties cultivated in collections from other countries, discovered incorrect records of the accessions, and were able to rename the misnomered ones. Molecular methods provide scientific support for documenting inconsistencies and inaccuracies in ampelographic descriptions and complete the picture for description of all accessions present in germplasm collections. 
SSR markers for assessing genetic diversity in Romanian grapevine varieties

Statistics about the discriminatory efficiency of the 13 SSRs markers used are presented in Table 2. The high degree of genetic variability among the 50 cultivars is proven by the high number (112) of different alleles. With analysed accessions, the number of different alleles per locus ranged from 6 for VVMD25 and ISV4 to 13 for VVMD28, with an average of 8.62 , comparable to the results obtained in other laboratories (Westman et al., 1997; Salayeva et al., 2010). The highest Ne was for VVMD28 locus (8.16), while the lowest for ISV3 locus (2.74) with the mean value of 4.84 . Mean observed heterozygosity (82.9\%) showed to be higher than that reported for other grapevine germplasm collections, like Iran with 76\% (Fatahi et al., 2003) and Spain with 70.7\% (Ibanez et al., 2003), and comparable to the values obtained by Carimi et al. (2010) and Lacombe et al. (2013).

For microsatellite markers efficiency were considered observed and expected heterozygosity $(\mathrm{Ho}, \mathrm{He}$ ) to evaluate the genetic variability among analysed grapevine. Ho ranged from 0.64 for VVS2 to 0.93 for VVMD5; mean Ho was slightly higher (0.829) than the expected one (0.784), with great differences locus by locus.

The ability of microsatellites to identify grapevine varieties is linked to the polymorphic information content (PIC) (Weber, 1990) and the probability of identity (PI) (Paetkau et al., 1995). The correspondence between these parameters is the following: an SSR effective in discriminating among genotypes has high levels of $\mathrm{Ho}, \mathrm{He}$ and PIC, and low PI values (Salayeva et al., 2010). Among the four additional SSR markers tested in the current study, were remarked the ISV4 and VMCNG4b9 markers which displayed high diversity levels regarding the expected heterozygosity (higher than mean value of 0,784 ), high values of PIC (higher than mean value of 0,742) "and low values of PI (in comparison with other markers).

In the present case, the PI values ranging from 0.028 to 0.200 and the combined PI value of 3.39E-15, classified all the 13 markers as effective in discriminating the analysed varieties and highly informative for proving genetic diversity among studied grapevine varieties. These values are in concordance with those presented by Lopes et al. (1999) and Sefc et al. (2000).

Null-allele frequency $\mathrm{F}$ (null) showed to be very interesting, because it was negative for 11 out of 13 SSRs. This parameter is valuable to reveal some problems with allele amplification during genotyping or a possible deletion in the target sequence. In the hereby study were obtained positive values for F (null) with VVS2 and VVMD28 markers indicating possibility of the presence of null alleles. With these two markers, were registered lower values of the observed heterozygosity in comparison with the expected ones, also probably due to the occurrence of null alleles at VVS2 and VVMD28 locus. Between these two markers, VVS2 was a little bit critical, despite the high number of alleles.

\section{Conclusions}

Variety identification is important to breeders, curators, grape growers, winemakers and grape and wine consumers and, also it is a proof of a good traceability system throughout producing of grapevine planting material and winemaking process. Beside ampelographic description, the DNA analyses are necessary to verify grapevine identity before acquisition for germplasm collection, distribution or exchange plant material, planting and establishing a vineyard or investing in wine production. The efficiency of the two methods used for the complete characterization of the autochthonous grapevine varieties represents overwhelming evidence for the necessity of further investigation of other accessions existing in germplasm collections. These data with entire documentation of plant material authenticity are essential for improving the knowledge on Romanian grape varieties, completing information on the existence of synonyms with other varieties in European germplasm collections, as well as identifying unique genotypes that require particular attention for preservation. The complete description and compliance with the requirements for European germplasm collections of each accession is the primary requirement for the exchange of genetic material among germplasm collections.

Table 2. Genetic markers (13 microsatellite loci) and parameters applied to analyze their effectiveness to highlight genetic variability from the grapevine germplasm collection

\begin{tabular}{|c|c|c|c|c|c|c|c|}
\hline Locus & $\mathrm{Na}$ & $\mathrm{Ne}$ & Ho & $\mathrm{He}$ & PIC & PI & $\mathrm{F}$ (null) \\
\hline VVS2 & 9 & 3,99 & 0,644 & 0,758 & 0,710 & 0,102 & +0.0831 \\
\hline VVMD5 & 8 & 7,23 & 0,933 & 0,871 & 0,846 & 0,035 & -0.0413 \\
\hline VVMD7 & 8 & 3,27 & 0,733 & 0,703 & 0,651 & 0,137 & -0.0197 \\
\hline VVMD25 & 6 & 4,09 & 0,822 & 0,765 & 0,713 & 0,103 & -0.0426 \\
\hline VVMD27 & 8 & 4,57 & 0,844 & 0,790 & 0,748 & 0,082 & -0.0400 \\
\hline VVMD28 & 13 & 8,16 & 0,867 & 0,887 & 0,865 & 0,028 & +0.0048 \\
\hline VVMD32 & 11 & 5,09 & 0,911 & 0,813 & 0,780 & 0,062 & -0.0660 \\
\hline VrZAG62 & 8 & 4,51 & 0,867 & 0,787 & 0,746 & 0,082 & -0.0534 \\
\hline VrZAG79 & 10 & 5,13 & 0,822 & 0,814 & 0,784 & 0,059 & -0.0118 \\
\hline ISV2 & 8 & 3,57 & 0,822 & 0,729 & 0,673 & 0,125 & -0.0721 \\
\hline ISV3 & 7 & 2,74 & 0,800 & 0,642 & 0,568 & 0,200 & -0.1233 \\
\hline ISV4 & 6 & 5,03 & 0,889 & 0,810 & 0,771 & 0,070 & -0.0522 \\
\hline VMCNG4B9 & 10 & 5,48 & 0,822 & 0,827 & 0,794 & 0,057 & -0.0024 \\
\hline Mean values & 8,62 & 4,84 & 0,829 & 0,784 & 0,742 & & \\
\hline Combined values & & & & & & $3,39 \mathrm{E}-15$ & \\
\hline
\end{tabular}

Na: number of alleles; Ne: number of effective alleles, Ho: observed heterozygosity; He: expected heterozygosity; PIC: Polymorphism information content, PI: probability of identity, $\mathrm{F}$ (null): probability of null alleles 
198

\section{Acknowledgements}

The results were obtained within the framework of the COST project - Action FA1003 "East-West Collaboration for Grapevine Diversity Exploration and Mobilization of Adaptive Traits for Breeding". Analyzed plant material was used to establish the grapevine ex situ collection through ADER 3.1.3. project.

\section{References}

Bodea M, Pamfil D, Pop R, Pop IF (2009). Use of random amplified polymorphic DNA to study genetic diversity anong Romanian local vine (Vitis vinifera L.) cultivars. Bulletin of University of Agricultural Sciences and Veterinary Medicine Cluj-Napoca. Horticulture 66(2):1722.

Butiuc-Keul AL, Craciunas C, Coste A, Fagaro M (2010). Discrimination and genetic polymorphism of several cultivars of grapevine by RAPD markers. Romanian Biotechnological Letters 15(1):110-115.

Carimi F, Mercati F, Abbate L, Sunseri F (2010). Microsatellite analyses for evaluation of genetic diversity among Sicilian grapevine cultivars. Genetic Resources and CropEvolution 57(5):703-719.

Constantinescu G, Negreanu E, Lăzărescu V, Poenaru I, Alexei O, Boureanu C (1959). Ampelografia Republicii Populare Române. Vol. II, Editura Academiei R.P.R, Bucuresti, Romania.

Constantinescu G, NegreanuE, Lăzărescu V, Poenaru I, Alexei O, Boureanu C (1960). Ampelografia R.R.R Vol III, Editura Academiei R.P.R, Bucuresti, Romania.

Constantinescu G, Negreanu E, Lăzărescu V, Poenaru I, Alexei O, Mihalca G (1961). Ampelografia Republicii Populare Române. Vol. IV, Editura Academiei R.P.R, Bucuresti, Romania.

Constantinescu G, NegreanuE, Lăzărescu V, Poenaru I, Alexei O, Boureanu C (1965). Ampelografia Republicii Populare Române. Vol. VI, Editura Academiei R.P.R, Bucuresti, Romania.

Constantinescu G, Negreanu E, Lăzărescu V, Poenaru I (1966). Ampelografia Republicii Socialiste Romania. Vol VII, Editura Academiei R.S.R. Bucuresti, Romania.

Coste A, Postolache D, Popescu F, Butiuc-Keul A L (2010). Authentication of valuable grapevine varieties from Romania through molecular markers. Romanian Biotechnological Letters 15(1):3-11.

Fatahi R, Ebadi A, Bassil N, Mehlenbacher SA, Zamani Z (2003). Characterization of Iranian grapevine cultivars using microsatellite markers. Vitis 42:185-192.

Ibanez J, Andre's MT, Molino A, Borrego J (2003). Genetic study of key Spanish grapevine varieties using microsatellites analysis. American Journal of Enology and Viticulture 54:22-29.

Indreas A, Visan L (2001). Principalele soiuri de struguri pentru vin cultivate in Romania [Main varieties of grapes for wine grown in Romania]. Editura Ceres, Bucuresti, Romania.

Gheorghe RN, Popescu CF, Pamfil D, Pauchnecht AE (2008). Genetic diversity evaluation of some autochthonous grapevine varieties by RAPD markers. Lucrări ştiințifice Universitatea de Ştiințe Agricole şi Medicină Veterinară "Ion Ionescu de la Brad” Iaşi - seria Horticultură 51:73-76.

GhețeaLG, Motoc RM, Popescu CF, Barbacar N, Iancu D, Constantinescu C, Barbarii LE (2010). Genetic profiling of nine grapevine cultivars from Romania, based on SSR markers. Romanian Biotechnological Letters 15(1):116-124.
Ghețea LG, Motoc RM, Popescu CF, Bărbăcar N, Bărbării LE, Constantinescu C, ... Savin G (2012). Assessment of diversity in grapevine gene pools from Romania and Republic of Moldova, based on SSR markers analysis. In: Luna Maldonado AI (Ed). Horticulture. InTech, Rijeka, Croatiapp 43-60.

Lacombe T, Boursiquot JM, Laucou V, Di Vecchi-Staraz M, Peros JP, This $P$ (2013). Large-scale parentage analysis in an extended set of grapevine cultivars (Vitis vinifera L.). Theoretical Applied Genetics 126 (2):401414.

Lopes MS, Sefc KM, Eiras Dias E, Steinkellner H, Laimer da Camara Machado M, Laimer da Camara Machado A (1999). The use of microsatellites for germplasm management in a Portuguese grapevine collection. Theoretical and Applied Genetics 99:733-739.

Maletić E, Sefc KM, Steinkellner H, Kontić JK, Pejić I (1999). Genetic characterization of Croatian grapevine cultivars and detection of synonymous cultivars in neighbouring regions. Vitis 38:79-83.

Maul E, Sudharma KN, KeckeS, Marx G, Müller C, Audeguin L, ... Simon S (2012). The European Vitis Database (www.eu-vitis.de) - a technical innovation through an online uploading and interactive modification system. Vitis 51:79-86.

Migiaro D, Morreale G, Gardiman M, Landolfo S, Crespan M (2013). A third-generation DNA polymerase coupled with a multiplex PCR system speed up diagnostics for grapevines identification. Plant Genetic Resources 11:182-185.

OIV (2009). OIV Descriptors List for Grape Varieties and Vitis Species. ( $2^{\text {nd }}$ edition). Paris: Organisation internationale de la vigne et du vin [International Organisation of Vine and Wine] France.

Paetkau D, Calvert W, Stirling I, Strobeck C (1995). Microsatellite analysis of population structure in Canadian polar bears. Molecular Ecology 4:347-354.

Popescu CF, Maul E, Dejeu LC, Dinu D, Gheorge RN, Laucou V, et al., Crespan M (2017). Identification and characterization of Romanian grapevine genetic resources. Vitis 56:173-180.

Rotaru L (2009). Soiuri de vita de vie pentru struguri de vin [Grapevine varieties for wine grapes]. Ed. Ion Ionescu de la Brad Iasi, Romania.

Salayeva S, Decroocq S, Mariette S, Akhundova E (2010). Comparison of genetic diversity between cultivated and wild grape varieties originating from the near-Caspian zone of Azerbaijan. Journal International des Sciences dela Vigne et du Vin 44(4):191-200.

Sefc KM, Lopes MS, Lefort F, Botta R, Roubelakis-Angelakis KA, Ibanez J, Pejic I, Wagner HW, Glossl J, Steinkellner H (2000). Microsatellite variability in grapevine cultivars from different European regions and evaluation of assignment testing to assess the geographic origin of cultivars. Theoretical and Applied Genetics 100:498-505.

Tassie L (2010). Vine identification - knowing what you have. In: Grape and wine research and development corporation - Australian Government. GW RDC Innovators Network, Greenhill Road Wayville.

Thomas MR, Matsumoto S, Cain P, Scott NS (1993). Repetitive DNA of grapevine: classes present and sequences suitable for cultivar identification. Theoretical and Applied Genetics 86:173-180.

Weber JL (1990). Informativeness of human (dC-dA)n-(dGdT)n polymorphisms. Genomics 7:524530.

Westman AL, Kresovich S (1997). Use of molecular markers techniques for description of plant genetic variation. In: Callow JA, Ford-Lloyd BV, Newbury HJ (Eds). Biotechnology and Plant Genetic Resources: Conservation and Use. CAB International, Wallingford, UK pp 9-48. 